PREGLEDNI RAD

UDK: 657.375

Prof. dr. sc. Boris Tušek *

Dr. sc. Dragan Gabrić ${ }^{* *}$

\title{
ANALIZA NOVČANIH POKAZATELJA KVALITETE DOBITI U FUNKCIJI UTVRĐIVANJA RAC̆UNOVODSTVENIH MANIPULACIJA U FINANCIJSKIM IZVJEŠTAJIMA KOTIRAJUĆIH PODUZEĆA U FEDERACIJI BIH
}

\author{
ANALYSIS OF EARNING QUALITY CASH INDICATORS IN \\ THE FUNCTION OF DETERMINATION OF ACCOUNTING \\ MANIPULATIONS IN THE FINANCIAL STATEMENTS OF THE \\ LISTED COMPANIES - EVIDENCE FROM FEDERATION OF B\&H
}

\begin{abstract}
SAŽETAK: Financijski izvještaji opće namjene predstavljaju važan izvor informacija za potrebe poslovnog odlučivanja te je od iznimne važnosti da financijski izvještaji budu realno i istinito prezentirani. Predmet ovoga rada je istraživanje utjecaja novčanih pokazatelja kvalitete dobiti na utvrđivanje računovodstvenih manipulacija u financijskim izvještajima poduzeća. Osnovni cilj ovoga istraživanja je oblikovanje modela utjecaja novčanih pokazatelja kvalitete dobiti na utvrđivanje računovodstvenih manipulacija u financijskim izvještajima poduzeća te utvrđivanje novčanih pokazatelja kvalitete dobiti koji doprinose utvrđivanju računovodstvenih manipulacija u financijskim izvještajima kotirajućih poduzeća u Federaciji BiH. Prikupljeni podaci analizirani su primjenom metoda inferencijalne statistike, a dobiveni rezultati su prezentirani pomoću tabličnih prikaza. Rezultati istraživanja pokazuju da novčani pokazatelji kvalitete dobiti doprinose utvrđivanju računovodstvenih manipulacija u financijskim izvještajima kotirajućih poduzeća u Federaciji BiH.
\end{abstract}

KLJUČNE RIJEČI: financijski izvještaji, računovodstvene manipulacije, novčani pokazatelji, kvaliteta dobiti.

JEL KLASIFIKACIJA: M40

ABSTRACT: The financial statements of general purpose are important source of information for purpose of business decision-making. Therefore, it is important to present financial statements fairly and faithfully without material misstatement. The subject of this

Redoviti profesor u trajnom zvanju, Ekonomski fakultet Sveučilišta u Zagrebu, Trg J.F. Kennedyja 6, Zagreb.

** Sveučilište u Mostaru, Trg hrvatskih velikana 1, Mostar. 
paper is to explore the impact of earning quality cash indicators on the determination of accounting manipulations in the financial statements. The main objective of this research is to create a model of an impact of the earning quality cash indicators on determination of accounting manipulations in financial statements of the listed companies in the Federation of $\mathrm{B} \& \mathrm{H}$. Identification of earning quality cash indicators that contribute to the determination of accounting manipulations in the financial statements is also one of the objectives of this research. The collected data were analysed by inferential statistical methods, and the tables have used to present the research results. Research results revealed that the earning quality cash indicators have a contribution to the determination of accounting manipulations in the financial statements of the listed companies in the Federation of $\mathrm{B} \& \mathrm{H}$.

KEY WORDS: financial statements, accounting manipulations, cash indicators, earning quality

JEL CLASSIFICATION: M40

\section{UVOD}

Financijski izvještaji predstavljaju važan izvor informacija za poslovno odlučivanje. Realne i objektivne računovodstvene informacije jedan su od neophodnih preduvjeta za poslovno odlučivanje svih interesnih strana (engl. stakeholdera). „Cilj je financijskih izvještaja opće namjene pružiti informacije o financijskom položaju, financijskoj uspješnosti i novčanim tokovima poslovnog subjekta koje su korisne širokom krugu korisnika u donošenju ekonomskih odluka.“ (MRS $1^{1}$, t. 9.). Međunarodni računovodstveni standardi polaze od pretpostavke da financijski izvještaji realno prikazuju financijski položaj, financijsku uspješnost i novčane tokove subjekta. Međutim, postoji i druga krajnost, a to je nerealno i neistinito financijsko izvještavanje koje podrazumijeva da financijski izvještaji sadrže značajna pogrešna prikazivanja. Od posebnog je interesa za sve korisnike financijskih izvještaja, da isti budu bez značajnih pogrešnih prikazivanja.

Istraživanja koja u središtu svoga interesa imaju analizu i ispitivanje kvalitete financijskih izvještaja, mjerene prije svega kroz pojavu i intenzitet značajnih pogrešaka i računovodstvenih manipulacija su uvijek aktualna i zanimljiva znanstvenoj i stručnoj javnosti. To prije svega vrijedi za američku znanstvenu i istraživačku zajednicu, dok ,,manja zastupljenost istraživanja računovodstvenih pogrešaka i manipulacija u financijskim izvještajima na europskom području proizlazi iz manje transparentnih tržišta kapitala i otpora (manjka volje) poduzeća da javno objave potpuni set financijskih izvještaja." (Aljinović Barač i Klepo, 2006., str. 274.). U tome kontekstu, cilj ovoga istraživanja je oblikovanje modela utjecaja novčanih pokazatelja kvalitete dobiti na utvrđivanje računovodstvenih manipulacija u financijskim izvještajima poduzeća te utvrđivanje pokazatelja kvalitete dobiti koji doprinose utvrđivanju računovodstvenih manipulacija u financijskim izvještajima. Pokazatelji analize financijskih izvještaja predstavljaju važan izvor informacija o poslovanju poduzeća, ali i strukturi i kvaliteti financijskih izvještaja. Stoga se u ovome radu polazi od pretpostavke da pokazatelji kvalitete dobiti kao rezultat analize financijskih izvještaja pozitivno utječu na utvrđivanje računovodstvenih manipulacija u financijskim izvještajima poduzeća. Kroz

MRS 1 - Prezentiranje financijskih izvještaja. 
više istraživanja, sugerira se unaprjeđenje postojećih modela koji na određeni način razmatraju i dovode u vezu različite pokazatelje s utvrđivanjem računovodstvenih manipulacija u financijskim izvještajima (Dechow, Weili Ge, Larson i Sloan, 2010.; Bayley i Taylor, 2007.; Prevoo, 2007.).

\section{PREGLED RELEVANTNIH ISTRAŽIVANJA}

Dosadašnja istraživanja o kvaliteti financijskih izvještaja u najvećoj mjeri su se bazirala na analiziranju mjera obračunskih veličina (Jones, 1991.; Dechow i Dichev, 2002.), kao i istraživanju odabranih i posebno razvijenih financijskih i nefinancijskih pokazatelja te njihovome utjecaju na utvrđivanje i predviđanje značajnog pogrešnog prikazivanja i računovodstvenih manipulacija (Beneish, 1999.; Dechow i suradnici, 2010.). Dva vrlo važna rada iz područja kvalitete financijskih izvještaja su autora Messoda Beneisha iz 1997. i 1999. godine. Beneish (1997.) je u prvome istraživanju analizirao financijske izvještaje 64 poduzeća sa značajnim pogrešnim prikazivanjima te je utvrdio da su pokazatelji „trajanje naplate potraživanja“ te ,primarna uspješnost“ ključni za klasificiranje poduzeća u pogledu računovodstvenih manipulacija u financijskim izvještajima. U dodatnome istraživanju (Beneish, 1999.) pokazano je da su pokazatelji prosječnog trajanja naplate potraživanja, indeks kretanja bruto marže, indeks kvalitete imovine, indeks kretanja prodaje i obračunske veličine, ključni faktori koje utječu na kvalitetu financijskih izvještaja. Drugi značajni model koji se temelji na financijskim i nefinancijskim pokazateljima je F-model koji je rezultat istraživanja iz 2008. godine (Dechow i suradnici, 2010.). Utvrđeno je da poduzeća s računovodstvenim manipulacijama u financijskim izvještajima imaju visoke obračunske veličine i visok udio imovine čija se nabavna vrijednost dobrim dijelom utvrđuje temeljem diskrecijske procjene uprave. Od nefinancijskih mjera, udio najmova je bio u porastu, a broj zaposlenika u značajnome opadanju kod poduzeća čiji financijski izvještaji sadrže računovodstvene manipulacije.

Godine 2002. Dechow i Dichev razvili su model procjene kvalitete financijskih izvještaja na temelju kvalitete obračunskih veličina u financijskim izvještajima. Model se temelji na pretpostavci da se kvaliteta računovodstvenih informacija iz financijskih izvještaja smanjuje obrnuto proporcionalno s povećanjem računovodstvenih pogrešaka u iskazivanju obračunskih veličina u financijskim izvještajima. Empirijska mjera kvalitete obračunske veličine u financijskim izvještajima je stupanj u kojemu se obračunani i iskazani radni kapital može objasniti realiziranim (naplaćenim) novčanim tokom, s naznakom da manja naplaćenost odnosno mogućnost pokrića prethodno priznatih obračunskih veličina realiziranim novčanim tokom, znači i manju kvalitetu iskazanih obračunskih veličina, a samim time i manju kvalitetu financijskih izvještaja odnosno veću vjerojatnost računovodstvenih manipulacija u financijskim izvještajima. Kao osnovna kritika na ovaj, kao i ostale modele koji se temelje na mjerenju obračunskih veličina, ističe se slaba prediktivna sposobnost.

Uloga financijskih pokazatelja u utvrđivanju poslovnih događaja je nesporna (neupitna, nedvojbena) i pokazana u prethodnome razdoblju za potrebe previđanja bankrota (Altman, 1968.), ali i drugih poslovnih događaja kao što su smanjenje poslovanja ili povećanje kapitala (Korcan i suradnici, 2013., str. 1-75.). Međutim, također se sugeriraju dodatna istraživanja koja bi dodatno istražila utjecaj financijskih pokazatelja na utvrđivanje kvalitete 
financijskih izvještaja (Korcan i suradnici, 2013., str. 1-75.). Također, sugeriraju se dodatna istraživanja koja bi u fokusu interesa imala utjecaj financijskih pokazatelja, između ostaloga i pokazatelja novčanog toka, na utvrđivanje kvalitete financijskih izvještaja poduzeća odnosno računovodstvenih manipulacija u financijskim izvještajima poduzeća (Korcan, Dechow, Yuan i Wang, 2013.; Dechow i suradnici, 2010.). Nadalje, postojeća istraživanja o povezanosti između određenih i odabranih financijskih pokazatelja i kvalitete financijskih izvještaja su većinom zastupljena u zemljama anglosaksonskog govornog područja (Cuzdriorean, 2013.) čije se karakteristike institucionalnog okvira poslovanja značajno razlikuju u odnosu na europske i domaće uvjete.

\section{OBLIKOVANJE MODELA ISTRAŽIVANJA}

\subsection{Analitičko predstavljanje modela istraživanja}

Metodološki pristup istraživanju kvalitete financijskih izvještaja podrazumijeva načine istraživanja i analiziranja računovodstvenih manipulacija i značajnih pogrešnih prikazivanja u financijskim izvještajima. S time u vezi, moguće je identificirati tri osnovna metodološka pristupa istraživanju značajnih pogrešnih prikazivanja i računovodstvenih manipulacija u financijskim izvještajima:

1. istraživanja računovodstvenih manipulacija utemeljena na obračunskim veličinama

2. istraživanja računovodstvenih manipulacija utemeljena na financijskim i nefinancijskim pokazateljima i

3. alternativni pristupi istraživanja računovodstvenih manipulacija.

U konkretnome slučaju, za potrebe ovoga istraživanja polazi se od metodološkog pristupa utemeljenoga na financijskim pokazateljima kvalitete dobiti koji se temelje na novčanoj osnovi. Osnovni cilj ovoga istraživanja je utvrđivanje novčanih pokazatelja kvalitete dobiti koji doprinose utvrđivanju računovodstvenih manipulacija u financijskim izvještajima. U razvoju konceptualnog modela istraživanja polazi se od pretpostavke da su pokazatelji kvalitete dobiti, koji se temelje na novčanoj osnovi, u funkciji utvrđivanja računovodstvenih manipulacija u financijskim izvještajima. Model istraživanja može se predstaviti u obliku jednadžbe višestruke linearne regresije:

$$
\mathbf{M M}_{\mathrm{i}, \mathrm{t}}=\beta_{0 \mathrm{i}, \mathrm{t}}+\beta_{1} \mathrm{QRev}_{\mathrm{i}, \mathrm{t}}+\beta_{2} \mathrm{QPrO}_{\mathrm{i}, \mathrm{t}}+\varepsilon_{\mathrm{i}, \mathrm{t}}
$$

gdje je

MM - Računovodstvene manipulacije u financijskim izvještajima

$\beta_{0}, \beta_{1, \ldots .,} \beta_{n}$ - Parametri (koeficijenti) uz nezavisne varijable

QRev - Kvaliteta prodaje

QPro - Kvaliteta dobiti

$\varepsilon_{i, t} \quad-$ Statistička (slučajna) pogreška

i,t - za poduzeće $i$, u razdoblju $t$ 
Prema postavljenom modelu istraživanja, računovodstvene manipulacije u financijskim izvještajima su definirane kao zavisna varijabla, a pokazatelji kvalitete prodaje i kvalitete dobiti kao nezavisne varijable. Cilj ovako koncipiranoga modela je prikazati da novčani pokazatelji kvalitete dobiti doprinose utvrđivanju računovodstvenih manipulacija u financijskim izvještajima kotirajućih poduzeća. Naime, pokazatelji analize financijskih izvještaja (kako oni temeljeni na obračunskom, tako i oni temeljeni na novčanoj osnovi) utvrđuju se na temelju informacija iz financijskih izvještaja, a informacije u financijskim izvještajima su rezultat evidentiranih podataka o poduzetim transakcijama i ostalim poslovnim događajima poduzeća u promatranome obračunskom razdoblju. Sukladno tome, računovodstvene manipulacije koje su uključene u financijske izvještaje nastaju u fazama računovodstvenog procesa koje prethode prezentiranju financijskih izvještaja korisnicima. Ovako koncipiran model istraživanja ne znači da računovodstvene manipulacije u financijskim izvještajima ovise o vrijednosti novčanih pokazatelja kvalitete dobiti. Upravo suprotno, s obzirom da nastanak računovodstvenih manipulacija prethodi izračunu pokazatelja, cilj je utvrditi novčane pokazatelje kvalitete dobiti koji ukazuju na stavke financijskih izvještaja koje su zahvaćene računovodstvenim manipulacijama te sukladno tome imaju značajnu determinističku sposobnost za utvrđivanje računovodstvenih manipulacija u financijskim izvještajima kotirajućih poduzeća.

\subsection{Pojmovno određenje računovodstvenih manipulacija u financijskim izvještajima}

Postoji posebno područje u okviru računovodstvene i revizijske teorije koje se bavi istraživanjima različitih faktora te analiziranjem njihovoga utjecaja na kvalitetu financijskih izvještaja odnosno na realnost i objektivnost financijskih izvještaja. U računovodstvenoj i revizijskoj teoriji to područje je poznato pod nazivom „upravljanje zaradama“ (engl. Earnings management). U nekim slučajevima koriste se i pojmovi manipulativnog računovodstva, računovodstva manipulacija i kreativnog računovodstva, ali se za potrebe ovoga rada može zauzeti pristup da se radi o pojmovima koji označavaju jedno područje istraživanja utjecaja različitih faktora na kvalitetu financijskih izvještaja. Pojam „upravljanje zaradama“ najčešće podrazumijeva poduzimanje određenih intervencija u računovodstvenome procesu koje za cilj imaju modifikaciju referentnih računovodstvenih veličina odnosno modifikaciju percepcije rizičnosti koju korisnici financijskih izvještaja imaju o poslovanju poduzeća (Stolowy i Breton, 2000.). „Računovodstveno manipuliranje nastaje kada menadžeri koriste prosudbu u procesu financijskog izvještavanja i strukturiranju transakcija te na taj način modificiraju financijske izvještaje s ciljem pogrešnog informiranja korisnika ili s ciljem utjecaja na ugovorne ishode koji ovise o računovodstvenim brojevima." (Healy i Whalen, 1999., str. 368.). Prema Ronenu i Yaariju (2008.) računovodstveno manipuliranje javlja se kao posljedica poduzimanja proizvodno/investicijskih akcija prije nego što su zarade realizirane ili izbora računovodstvenih politika kojima se utječe na računovodstvene zarade i njihovu interpretaciju nakon što su stvarne zarade realizirane. Ono što je zajedničko svim definicijama jest da upravljanje zaradama ili manipulativno računovodstvo s praktičnog aspekta predstavlja skup računovodstvenih postupaka i tehnika koje uprava kao interesna strana u poduzeću koristi da bi utjecala na iskazivanje i vrednovanje uspješnosti poslovanja, financijskog položaja i novčanih tokova, s ciljem ostvarivanja određenih oportunističkih ciljeva. 
Kao rezultat poduzetih aktivnosti javljaju se računovodstvene manipulacije u financijskim izvještajima. „U većini slučajeva, računovodstvene manipulacije se mogu definirati kao poduzimanje oportunističkih računovodstvenih procjena iznosa s namjerom pogrešnog informiranja korisnika financijskih izvještaja.“ (Aljinović Barač, Klepo, 2006., str. 275.) Schipper (1989., str. 2.), primjerice definira računovodstvene manipulacije kao svrsishodne intervencije u eksternom financijskom izvještavanju s namjerom pribavljanja nekih privatnih koristi." (citirano prema Aljinović Barač i Klepo, 2006., str. 275.). Gulin (2002., str. 34.) ističe da iako pojam „manipulacije“ izaziva negative konotacije povezane s nezakonitim aktivnostima, nisu sve manipulacije u pravilu nezakonite. $U$ većini situacija manipulacije podrazumijevaju aktivnosti i učinke tih aktivnosti koje su u okviru zakona, dok prijevare u financijskim izvještajima podrazumijevaju poduzimanje aktivnosti koje su izvan zakonskih normi (vidjeti Dechow i Skinner, 2000.). Prema Aljinović Barać i Klepo (2006.) „računovodstvene manipulacije se u pravilu mogu definirati kao manipuliranje računovodstvenim brojevima koje nije u skladu s načelima istinitog i fer prezentiranja.“ (str. 275.). Prema Jamesonu (1988., str. 20.) „,računovodstveno manipuliranje se može opisati kao proces koji može biti u okviru pravila zakona i računovodstvenih standarda, ali je očito da je u suprotnosti s načelima zakona i općeprihvaćenih računovodstvenih standarda.“

Prema Međunarodnim standardima financijskog izvještavanja (MSFI) računovodstvene manipulacije podrazumijevaju financijske izvještaje koji sadrže značajna pogrešna prikazivanja odnosno materijalno značajne pogreške. Nadalje, prema računovodstvenom i etimološkom pristupu značajno pogrešno prikazivanje može se definirati kao pogrešno prikazivanje stavki financijskih izvještaja koje su značajne u vrijednosnom smislu, a koje mogu biti posljedica propusta, previda, pogrešnih procjena ili izostavljanja u prikazivanju. „Pogreška je značajna ako može, pojedinačno ili skupno, utjecati na ekonomske odluke koje korisnici donose na osnovi financijskih izvještaja. Značajnost ovisi o kombinaciji veličine i vrste izostavljene ili pogrešno prikazane stavke financijskih izvještaja.“ (MRS-u $8^{2}, t$. 5.). Računovodstvene manipulacije u financijskim izvještajima mogu nastati u vezi s priznavanjem, mjerenjem, prezentiranjem ili objavljivanjem elemenata financijskih izvještaja. Razloge za nastanak pogrešaka treba tražiti u nedostatku informacija, pogrešnoj procjeni određenog poslovnog događaja ili financijskog učinka transakcije, neznanja, ili u konačnici, namjeri za pogrešno prikazivanje, što implicira prijevarno financijsko izvještavanje.

Za potrebe ovoga istraživanja računovodstvene manipulacije podrazumijevaju financijske izvještaje koje sadrže utvrđene značajne pogreške ili prijevare. Prema MRevS-u 240 (t. 4.) ,pogrešno prikazivanje u financijskim izvještajima može nastati zbog prijevare ili pogreške.“ Prema MRevS-u 240 (t. 4.) ,ključni čimbenik za razlikovanje prijevare od pogreške jest je li namjerna ili nenamjerna ona posljedična aktivnost koja rezultira pogrešnim prikazivanjem financijskih izvještaja." Prema kriteriju namjere nastanka, mogu se razlikovati:

- nenamjerna značajna pogrešna prikazivanja odnosno pogreške i

- namjerna značajna pogrešna prikazivanja odnosno prijevare. ${ }^{3}$

MRS 8 - Računovodstvene politike, promjene računovodstvenih procjena i pogreške.

Iako je prijevara široki pravni pojam, za svrhe ovoga MRevS-a, revizor je usmjeren samo na prijevare koje uzrokuju značajno pogrešno prikazivanje financijskih izvještaja. Revizori ne donose pravne odluke o tome je li se prijevara doista dogodila. Prijevara u koju su uključeni jedan ili više članova uprave ili onih koji su zaduženi za upravljanje naziva se "prijevara od strane uprave«. Prijevara koja uključuje samo zaposlenike naziva se "prijevara od strane zaposlenika «. U oba slučaja može postojati tajni sporazum unutar subjekta ili s trećim osobama izvan subjekta. (MRevS 240, t. 6.) 
Nenamjerna značajna pogrešna prikazivanja su posljedica značajnih računovodstvenih pogreški nastalih zbog propusta ili previda, ali bez namjere da pogreška nastane. Izraz „,pogreška“ odnosi se na nenamjerne pogreške u financijskim izvještajima. (MRevS 240, t. 5.). „Izraz ,prijevara“ odnosi se na namjernu radnju stjecanja nepravedne ili nezakonite prednosti varanjem, koju provodi jedna ili više osoba iz uprave, osobe iz nadzornog odbora, zaposlenici ili treća stranka.“ (MRevS 240, t. 6.).

Prema kriteriju područja nastanka mogu se razlikovati:

- računovodstvene manipulacije u vezi elemenata uspješnosti poslovanja

- računovodstvene manipulacije u vezi elemenata financijskog položaja i

- računovodstvene manipulacije u vezi elemenata novčanih tokova.

Računovodstvene manipulacije u vezi elemenata uspješnosti poslovanja proizlaze iz značajnih računovodstvenih pogrešaka ili prijevara u vezi priznavanja i mjerenja prihoda, rashoda i rezultata poslovanja kao elemenata uspješnosti poslovanja poduzeća, i vidljivi su prije svega u bilanci uspjeha. Računovodstvene manipulacije u vezi elemenata financijskog položaja proizlaze iz značajnih računovodstvenih pogrešaka ili prijevara u vezi priznavanja i mjerenja imovine (sredstava), obveza i kapitala kao elemenata financijskog položaja i stanja i vidljivi su u bilanci stanja odnosno izvještaju o financijskome položaju na kraju razdoblja. Računovodstvene manipulacije u vezi elemenata novčanih tokova proizlaze iz značajnih računovodstvenih pogrešaka ili prijevara u vezi priznavanja i mjerenja novčanih primitaka i izdataka te neto novčanog toka poduzeća. Polazeći od činjenice da se računovodstveno evidentiranje te posljedično i financijsko izvještavanje, temelji na sustavu dvojnog knjigovodstva, u pravilu će učinci nastalih računovodstvenih manipulacija imati istovremeni utjecaj na kombinaciju elemenata financijske uspješnosti, financijskog položaja i novčanih tokova poduzeća. S obzirom na prethodno navedeno, ovu klasifikaciju ne treba promatrati kao isključivu, već kao uvjetnu i fleksibilnu.

Prema kriteriju priznavanja i mjerenja elemenata financijskih izvještaja, mogu se identificirati:

- računovodstvene manipulacije u vezi priznavanja elemenata financijskih izvještaja

- računovodstvene manipulacije u vezi mjerenja elemenata financijskih izvještaja i

- računovodstvene manipulacije u vezi priznavanja i mjerenja elemenata financijskih izvještaja.

Računovodstvene manipulacije u vezi priznavanja elemenata financijskih izvještaja proizlaze iz značajnih pogrešaka ili prijevara nastalih u postupku provjere kriterija i donošenju odluke o razdoblju priznavanja financijskih elemenata uspješnosti, stanja i novčanih tokova u financijskim izvještajima. Računovodstvene manipulacije u vezi mjerenja elemenata financijskih izvještaja proizlaze iz značajnih pogrešaka ili prijevara nastalih u postupku vrednovanja odnosno utvrđivanja vrijednosti i dodjeljivanja odgovarajućih iznosa financijskim elementima uspješnosti, stanja i novčanih tokova u financijskim izvještajima. Računovodstvene manipulacije u vezi priznavanja i mjerenja elemenata financijskih izvještaja proizlaze iz značajnih pogrešaka ili prijevara nastalih u postupku provjere kriterija i donošenju odluke o razdoblju priznavanja financijskih elemenata uspješnosti, stanja i novčanih tokova u financijskim izvještajima, kao i u postupku vrednovanja odnosno utvrđivanja vrijednosti i dodjeljivanja odgovarajućih iznosa financijskim elementima uspješnosti, stanja i novčanih tokova. Ovakve pogreške ili prijevare u vezi priznavanja i mjerenja u pra- 
vilu imaju utjecaj na izbor pogrešnog razdoblja prezentiranja i na pogrešno utvrđene vrijednosti i pogrešno utvrđene iznose elemenata uspješnosti, stanja i novčanih tokova priznate u financijskim izvještajima te izravno utječu na vremenski i vrijednosni učinak prezentiranja elemenata financijske uspješnosti, financijskog položaja i novčanih tokova.

\subsection{Pregled odabranih novčanih pokazatelja kvalitete dobiti}

Osnovna generička klasifikacija pokazatelja analize financijskih izvještaja podrazumijeva podjelu na pokazatelje koji se temelje na načelu nastanka događaja (akrualnom načelu) i pokazatelje koji se temelje na načelu blagajne (novčanom načelu). Između ove dvije skupine pokazatelja postoji razlika koja proizlazi iz činjenice da se prihodi i rashodi kao elementi financijske uspješnosti priznaju na obračunskoj osnovi (akrualno načelo) u trenutku nastanka događaja, dok se primitci i izdatci kao elementi izvještaja o novčanim tokovima priznaju na novčanoj osnovi (računovodstveno načelo blagajne) u trenutku kada je nastala promjena u stanju novca i novčanih ekvivalenata (bez obzira na trenutak nastanka događaja). U konkretnome istraživanju predmet analize su novčani pokazatelji koji mogu ukazati na kvalitetu dobiti.

Pokazatelji kvalitete dobiti zapravo pokazuju kolika je razlika odnosno jaz između novčanih primitaka i obračunatih te priznatih prihoda i dobiti u određenom razdoblju. Što je ova razlika manja, to je kvaliteta dobiti i prihoda veća. Vrijedi i obrnuto. Postoje različiti pristupi klasifikaciji novčanih pokazatelja kvalitete dobiti kao rezultata analize financijskih izvještaja. Novčani pokazatelji ocjene kvalitete dobiti izračunavaju se stavljanjem u odnos odgovarajućih kategorija iz izvještaja o novčanim tokovima i određenih stavki iz drugih financijskih izvještaja, kako je prikazano u tablici 1.

Tablica 1. Klasifikacija i način izračuna novčanih pokazatelja kvalitete dobiti

\begin{tabular}{|c|cc|}
\hline Naziv pokazatelja & Opis i način mjerenja \\
\hline Kvaliteta prodaje & $=\frac{\text { Novčani primitci s osnova prodaje }}{\text { Prihodi od prodaje }}$ \\
\hline Kvaliteta dobiti & $=\frac{\text { Novčani tok iz poslovnih aktivnosti }}{\text { Dobit iz poslovnih aktivnosti }}$ \\
\hline
\end{tabular}

Izvor: Žager K., Žager, L., Mamić Sačer i Sever, 2008., str. 243-296.

Pokazatelj kvalitete prodaje ukazuje na odnos ostvarenih novčanih primitaka temeljem prodaje i prihoda od prodaje. Idealna situacija bi bila kada bi ovaj pokazatelj imao vrijednost jedan $(1,00)$ i to bi označavalo situaciju kada su svi obračunani prihodi od prodaje ujedno i naplaćeni. Ovaj koeficijent može imati i vrijednost veću od jedan, i takva situacija bi bila kada je naplaćeno više potraživanja od prodaje koja se odnose na tekuće i prethodna razdoblja, od obračunanih prihoda u određenom tekućem razdoblju. Ipak, najčešća situacija je da su novčani primitci od potraživanja manji od ostvarenih i obračunanih prihoda. „Međutim, kako prihodi od prodaje koji su sastavni dio računa dobiti i gubitka predstavljaju prihode tekućeg obračunskog razdoblja, a novčani primitci s osnove prodaje u izvještaju o 
novčanom toku mogu nastati naplatom tekuće prodaje ili naplatom iz prethodnih razdoblja, to znači da se kroz ovaj pokazatelj dobiva tek prosječna usporedba primitaka i prihoda od prodaje.“ (Žager L. i suradnici, 2008., str. 290.).

Slična razmišljanja mogu se ponuditi i kod pokazatelja kvalitete dobiti. Naime, ovaj pokazatelj stavlja u odnos ostvareni novčani tok iz poslovnih aktivnosti i ostvarenu dobit iz poslovnih aktivnosti u određenome razdoblju. Ovdje se također može istaknuti mogućnost da se novčani tok od poslovnih aktivnosti jednim dijelom odnosi na primitke i izdatke iz ranijih razdoblja, dok se dobit od poslovnih aktivnosti odnosi isključivo na tekuće promatrano razdoblje te se može govoriti o pokazatelju prosječne kvalitete dobiti. Kod ovih pokazatelja treba težiti da vrijednost istih bude što bliža jedan $(1,00)$ ili veća od jedan.

Kao primjere koji mogu uzrokovati značajne razlike između vrijednosti tradicionalnih pokazatelja i pokazatelja novčanog toka u vezi kvalitete prodaje i dobiti, Figlewicz i Zeller (1991., str. 75.) navode:

- „liberalnija kreditna politika prema kupcima - na taj način se povećava prodaja, što će utjecati na povećanje neto dobiti, ali ne i na porast novčanog toka iz poslovnih aktivnosti $\mathrm{u}$ istom obujmu

- namjerno kašnjenje s plaćanjem obveza prema dobavljačima - time se povećava novčani tok iz poslovnih aktivnosti, a nema utjecaja na kategoriju dobiti

- niska vrijednost investicija - nepostojanje investicija koje će ostvariti pozitivne novčane tokove korištenjem tradicionalnih pokazatelja može se prikriti niskom stopom amortizacije postojeće imovine.“

Zbog prethodno navedenog, kod ocjene kvalitete prodaje i dobiti, potrebno je uzeti u obzir druge pokazatelje kao što su dani naplate potraživanja, te pokazatelja strukturne i komparativne analize financijskih izvještaja.

\section{METODOLOGIJA ISTRAŽIVANJA}

\subsection{Uzorak istraživanja}

Za potrebe empirijskog dijela ovoga istraživanja definiran je uzorak poduzeća s osnovnom i kontrolnom skupinom poduzeća. U osnovnu skupinu uzorka uključena su poduzeća čiji su financijski izvještaji sadržavali računovodstvene manipulacije, dok su u kontrolnu skupinu uzorka uključena sva ostala poduzeća čiji financijski izvještaji nisu sadržavali značajna pogrešna prikazivanja. Osnovnu i kontrolnu skupinu uzorka (vidjeti tablicu 2.) čine revidirani godišnji financijski izvještaji poduzeća čiji su vlasnički vrijednosni papiri ${ }^{4}$ (dionice) uvršteni na organiziranom tržištu kapitala u Federaciji Bosne i Hercegovine (Sarajevska burza - dalje: SASE).

\footnotetext{
“Vrijednosni papir”, u smislu Zakona o tržištu vrijednosnih papira („Službene novine Federacije Bosne i Hercegovine“ broj 85/08., 109/12.), prenosiva je isprava u nematerijaliziranom obliku - elektronskom zapisu, emitirana u seriji na osnovu koje se ostvaruju prava prema emitentu i vrši prijenos prava, u skladu sa zakonom i odlukom o emisiji.
} 
Tablica 2. Projektiranje uzorka istraživanja

\begin{tabular}{|l|r|}
\hline \multicolumn{1}{|c|}{ Opis } & Broj \\
\hline $\begin{array}{l}\text { Ukupan broj poduzeća na kotaciji, slobodnom primarnom i sekundarnom tržištu } \\
\text { na Sarajevskoj burzi }\end{array}$ & 208 \\
\hline Neaktivna poduzeća čijim se dionicama ne trguje (suspenzija i drugo) & $(12)$ \\
\hline Financijski subjekti i institucije & $\mathbf{1 7 5}$ \\
\hline UKUPNO broj poduzeća & 875 \\
\hline $\begin{array}{l}\text { Ukupan broj jedinica (opservacija) osnovne populacije u razdoblju od 2010. - } \\
\text { 2014. godine (175 x 5 godina) }\end{array}$ & $\mathbf{2 5 7}$ \\
\hline Ukupan broj jedinica u uzorku u razdoblju od 2010. - 2014. godine & \\
\hline
\end{tabular}

Izvor: vlastita izrada.

U prvome koraku, u uzorak je uključena ukupna populacija poduzeća čiji vrijednosni papiri kotiraju na Sarajevskoj burzi, a koju za potrebe ovoga istraživanja čine svi emitenti čiji su vrijednosni papiri uvršteni na segmente kotacije poduzeća (jedan emitent), primarnog slobodnog tržišta (29 poduzeća) i sekundarnog slobodnog tržišta (178 poduzeća), što čini populaciju od ukupno 208 poduzeća. U drugome koraku, iz ukupnoga uzorka isključena su sva poduzeća čiji vrijednosni papiri nisu aktivni, kao i financijske institucije zbog institucionalnih specifičnosti poslovanja.

Konačno, u uzorak je uključeno 117 poduzeća ili 66,86\% od ukupno odabrane populacije (175 poduzeća) u promatranome razdoblju, što je pokazatelj koji je na zadovoljavajućoj razini. Budući da su za neka poduzeća prikupljeni revidirani godišnji financijski izvještaji za jednu godinu, a za neke za više godina, onda je ukupan broj revidiranih godišnjih financijskih izvještaja koji su uključeni u konačni uzorak (osnovna i kontrolna skupina) 257 jedinica, što čini 29,37\% od ukupne populacije, što je pokazatelj koji je na zadovoljavajućoj i prihvatljivoj razini. Kada se govori o vremenskoj definiciji uzorka i kontrolnog uzorka za potrebe ovoga istraživanja, u uzorak su uključena poduzeća čiji su vlasnički vrijednosni papiri uvršteni na organizirano tržište kapitala odnosno segmente kotacije emitenata, primarnog i sekundarnog slobodnog tržišta Sarajevske burze, u petogodišnjemu razdoblju od 2010. godine do 2014. godine.

U pogledu obilježja poduzeća uključenih u uzorak zanimljivo je promotriti strukturu uzorka s obzirom na vlasničku strukturu, klasifikaciju ${ }^{5}$ i veličinu poduzeća. Deskriptivna statistika u vezi osnovnih obilježja poduzeća (vidjeti tablicu 3.) odnosno jedinica uključenih u uzorak, omogućuje uvid u mjere centralne tendencije i varijabilnosti obilježja uzorka.

Za potrebe rangiranja djelatnosti poduzeća uključenih u uzorak primijenjena su osnovna područja djelatnosti definirana kroz Klasifikaciju djelatnosti u Bosni i Hercegovini 2010, i to: poljoprivreda, prerađivačka industrija, energetika, građevinarstvo, trgovina na veliko i na malo, promet, prijevoz i skladištenje, informacije i komunikacije, usluge i ostale nespomenute djelatnosti. 
Tablica 3. Mjerenje centralne tendencije i varijabilnosti osnovnih obilježja uzorka

\begin{tabular}{|l|l|r|r|r|}
\hline \multicolumn{2}{|l|}{} & $\begin{array}{c}\text { Vlasnička } \\
\text { struktura }\end{array}$ & Djelatnost & Klasifikacija (veličina) \\
\hline \multirow{2}{*}{$\mathrm{N}$} & Valjano & 257 & 257 & 257 \\
\cline { 2 - 5 } & Nedostaje & 0 & 0 & 0 \\
\hline Srednja vrijednost & 1,78 & 4,03 & 2,21 \\
\hline Medijan & 1,00 & 3,00 & 2,00 \\
\hline Mod & 1,00 & 2,00 & 2,00 \\
\hline Standardna devijacija & 1,291 & 2,319 & 0,692 \\
\hline
\end{tabular}

Izvor: rezultati istraživanja (N=257); SPSS v.20.

U kontekstu vlasničke strukture poduzeća uključenih u uzorak, mjera dominantne vrijednosti (Mod=1,00) ukazuje da je najčešći oblik vlasničke strukture - privatno domaće vlasništvo. S druge strane, centralna vrijednost (medijan) dijeli uzorak na dva dijela i poprima vrijednost 1,00 , što znači da više od $50 \%$ poduzeća uključenih u uzorak ima strukturu kapitala s privatnim domaćim vlasništvom $(72,80 \%)$. Kada se raspravlja o osnovnoj djelatnosti poduzeća uključenih u uzorak, najveći broj poduzeća se bavi prerađivačkom industrijom (Mod=2,00). S druge strane, centralna vrijednost (medijan) dijeli uzorak na dva dijela i kod obilježja djelatnosti poprima vrijednost 3,00, što znači da više od $50 \%$ poduzeća uključenih u uzorak obavlja kao osnovnu djelatnost poljoprivredu, prerađivačku industriju ili djelatnost iz oblasti energetike. U pogledu klasifikacije odnosno veličine poduzeća, mjera dominantne vrijednosti (Mod=2,00) ukazuje da je najveći broj poduzeća uključenih u uzorak klasificirano kao srednje veliko poduzeća. S druge strane, $84,50 \%$ poduzeća uključenih u uzorak je klasificirano kao srednje veliko ili veliko poduzeće.

\subsection{Metode prikupljanja i obrade podataka}

Metodologija prikupljanja i obrade podataka podrazumijeva izbor odgovarajućih instrumenata prikupljanja, sistematizacije, klasifikacije i statističke obrade podataka. Podatci za potrebe empirijskoga dijela istraživanja prikupljeni su primjenom tehnike analize sadržaja revizorskih i financijskih izvještaja u razdoblju od 2010. godine do 2014. godine na uzorku poduzeća čiji vrijednosni papiri kotiraju na tržištu kapitala u Federaciji Bosne i Hercegovine.

Za potrebe empirijskoga dijela istraživanja u analizu su uključeni samo godišnji financijski izvještaji, budući da su ista objektom neovisne revizije financijskih izvještaja. Mjerenje zavisne varijable odnosno računovodstvenih manipulacija u financijskim izvještajima poduzeća realizirano je primjenom sljedećih pravila:

- Ukoliko je kroz neovisni revizorski izvještaj poduzeća iskazano pozitivno mišljenje bez modifikacija ili uz modifikaciju ${ }^{6}$ s isticanjem pitanja koja nemaju utjecaja na

6 Cilj Međunarodnog standarda revizije (MRevS) 701 Modifikacije izvješća neovisnog revizora je utemeljiti standarde i dati upute o okolnostima u kojima izvješće neovisnog revizora treba biti modificirano, kao i o obliku i sadržaju modifikacije revizorova izvješća u tim okolnostima. Ovaj Međunarodni revizijski standard opisuje način modificiranja teksta revizorova izvješća u sljedećim situacijama: 
revizorsko mišljenje (posebni naglasci), to podrazumijeva da financijski izvještaji poduzeća ne sadrže računovodstvene manipulacije te se zavisnoj varijabli dodjeljuje rang vrijednosti nula (0).

- Ukoliko je kroz neovisni revizorski izvještaj poduzeća iskazano modificirano revizorsko mišljenje s isticanjem pitanja koja imaju utjecaja na revizorsko mišljenje (revizorsko mišljenje s rezervom ${ }^{7}$, suzdržavanje od revizorskog mišljenja ${ }^{8}$, negativno revizorsko mišljenje ${ }^{9}$ ), to podrazumijeva da financijski izvještaji poduzeća sadrže računovodstvene manipulacije te se zavisnoj varijabli dodjeljuje rang vrijednosti jedan (1).

Nakon toga, podatci su unijeti u bazu podataka gdje je izvršeno rangiranje varijabli, klasifikacija varijabli i izračun potrebnih pokazatelja analize financijskih izvještaja. Podatci iz revizorskih izvještaja stavljeni su u odnos s odgovarajućim podatcima iz financijskih izvještaja za određeno poduzeće i u određenom razdoblju. U konačnici su podatci pregledani, oblikovani i pripremljeni na način primjeren za unos u statistički program za statističke analize i testiranja. Za te potrebe korišten je SPSS statistički programski paket (engl. SPSS - Statistical Package for Social Sciences). Za potrebe empirijskoga dijela istraživanja kao temeljni oblik znanstveno spoznajnoga procesa primijenjene su statističke metode koje uključuju primjenu deskriptivne i inferencijalne statistike, a dobiveni rezultati su prezentirani pomoću tabličnih prikaza. Konkretno, za potrebe utvrđivanja pokazatelja kvalitete dobiti koji značajno utječu na utvrđivanje računovodstvenih manipulacija u financijskim izvještajima poduzeća primijenjeni su testovi razlika i to neparametrijski Man-U-Whitney test, kao i binarna logistička regresija s obzirom na to podatci iz uzorka ne slijede normalnu distribuciju.

\section{DISKUSIJA REZULTATA ISTRAŽIVANJA}

Rezultati provedenoga istraživanja ukazuju na osnovna obilježja utvrđenih računovodstvenih manipulacija u financijskim izvještajima kotirajućih poduzeća u Federaciji BiH. Tablica 4. pokazuje da je u 95 slučajeva ili 36,97\% utvrđeno da financijski izvještaji poduzeća sadrže računovodstvene manipulacije. S druge strane, kod 162 slučaja ili 63,03\% nije iskazano kvalificirano revizorovo mišljenje s modifikacijama odnosno nisu utvrđene računovodstvene manipulacije u financijskim izvještajima.

- Pitanja koja ne utječu na revizorovo mišljenje: (a) Poseban naglasak

- Pitanja koja utječu na revizorovo mišljenje: (a) Mišljenje s rezervom, (b) Suzdržanost od mišljenja, ili (c) Negativno mišljenje.

$7 \quad$ Mišljenje s rezervom treba biti izraženo kada revizor zaključi da se ne može izraziti pozitivno mišljenje, ali pritom učinak neslaganja s upravom ili ograničenja djelokruga rada nije tako značajan i prevladavajući da bi zahtijevao negativno mišljenje ili suzdržanost od izražavanja mišljenja (MRevS 701, t. 12.).

$8 \quad$ Suzdržanost od mišljenja mora se izraziti kada je mogući učinak ograničenja djelokruga revizorova rada tako značajan i prevladavajući da revizor nije mogao prikupiti dovoljne i odgovarajuće revizijske dokaze, te stoga ne može izraziti mišljenje o financijskim izvještajima (MRevS 701, t. 13.).

9 Negativno se mišljenje mora izraziti kada je učinak neslaganja toliko značajan i prevladavajući za financijske izvještaje da je revizor zaključio kako izvješće s rezervom nije primjereno za obznanjivanje da financijski izvještaji dovode u zabludu ili su nepotpuni (MRevS 701, t. 12.). 
Tablica 4. Deskriptivna statistika za područja značajnog pogrešnog prikazivanja

\begin{tabular}{|l|l|r|}
\hline \multirow{2}{*}{$\mathrm{N}$} & Valjano & 95 \\
\cline { 2 - 3 } & Nedostaje & 162 \\
\hline Medijan & 6,00 \\
\hline Mod & 6,00 \\
\hline
\end{tabular}

Izvor: rezultati istraživanja (N=257); SPSS v. 20.

Mjera dominantne vrijednosti u konkretnome slučaju (Mod=6,00) ukazuje da najčešće područje financijskoga izvještavanja uz koje se povezuju računovodstvene manipulacije i značajne pogreške je stavka vrijednosnog usklađenja kratkotrajnih potraživanja. S druge strane, centralna vrijednost (medijan) poprima vrijednost 6,00 što znači da u više od 50\% slučajeva, točnije 54,70\% slučajeva utvrđenih računovodstvenih manipulacija odnosi se na stavke prihoda, amortizacije, rezerviranja za rizike i troškove te vrijednosna usklađenja potraživanja. Rezultati istraživanja (vidjeti grafikon 1.) pokazuju da se najčešća područja računovodstvenih manipulacija odnose na stavke vrijednosna usklađenja potraživanja $(\mathrm{n}=37$; $38,90 \%)$, umanjenje stalnih sredstava $(n=17 ; 17,90 \%)$ i umanjenje zaliha $(n=9 ; 9,50 \%)$.

Nadalje, rezultati istraživanja također pokazuju da je najveći udio financijskih izvještaja s računovodstvenim manipulacijama utvrđen kod poduzeća koja obavljaju djelatnost prerađivačke industrije $(43,00 \%)$ i energetike $(79,00 \%)$. Kada se govori o najčešćim područjima računovodstvenih manipulacija po djelatnostima može se istaknuti da su to u okviru prerađivačke industrije, vrijednosna usklađenja potraživanja (27,90\%), umanjenja vrijednosti stalnih sredstava $(23,30 \%)$, rezerviranja $(14,00 \%)$ i umanjenja vrijednosti zaliha $(1,60 \%)$. S druge strane, vrijednosna usklađenja $(59,10 \%)$ i revalorizacija stalnih sredstava $(18,20 \%)$ su najčešća područja računovodstvenih manipulacija kod poduzeća iz područja energetike.

Grafikon 1. Pregled najčešćih područja značajnih pogrešnih prikazivanja

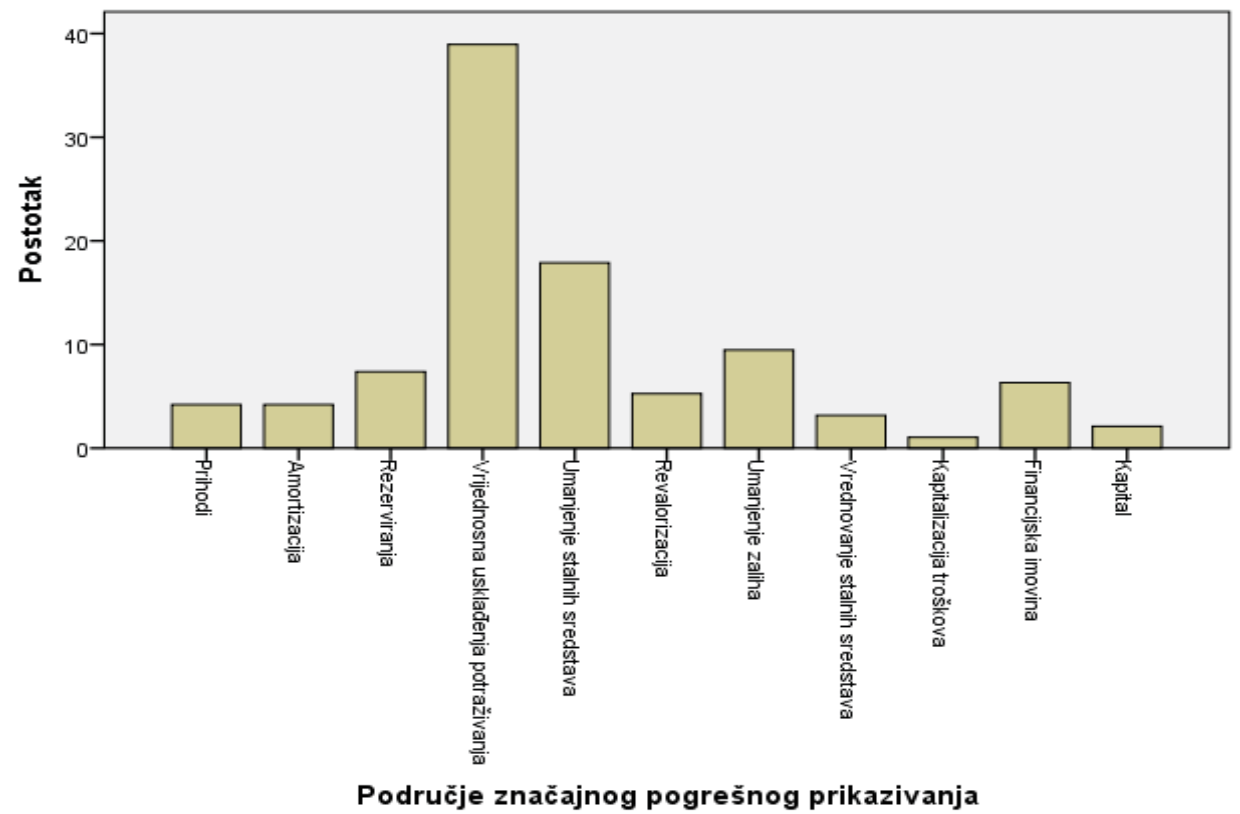

Izvor: rezultati istraživanja (N=257); SPSS v. 20. 
U pogledu analize obilježja računovodstvenih manipulacija s obzirom na veličinu poduzeća, rezultati pokazuju da najveći udio financijskih izvještaja s utvrđenim računovodstvenim manipulacijama imaju velika poduzeća $(42,60 \%)$. S druge strane, računovodstvene manipulacije su utvrđene u 37,40\% slučajeva srednje velikih poduzeća odnosno 22,00\% slučajeva poduzeća koja su klasificirana kao male pravne osobe. Kada se govori o najčešćim područjima računovodstvenih manipulacija prema veličini poduzeća onda se može istaknuti da u okviru srednje velikih poduzeća, kao skupine poduzeća s najvećim brojem utvrđenih računovodstvenih manipulacija, dominiraju područja vrijednosna usklađenja potraživanja $(37,00 \%)$, umanjenja vrijednosti stalnih sredstava $(19,60 \%)$ te rezerviranja za rizike i troškove $(13,00 \%)$. S druge strane, vrijednosna usklađenja potraživanja (42,50\%), umanjenje vrijednosti stalnih sredstava $(17,50 \%)$, umanjenje zaliha $(12,50 \%)$ i revalorizacija stalnih sredstava $(10,00 \%)$ su najčešća područja utvrđenih računovodstvenih manipulacija kod velikih poduzeća.

U pogledu predmeta ovoga istraživanja, pokazatelj kvalitete prodaje (QRev) i pokazatelj kvalitete dobiti (QPro) su pokazatelji analize financijskih izvještaja koji se, između ostaloga, dijelom temelje na novčanoj osnovi te su uključeni u statistička testiranja za potrebe ovoga istraživanja. Pokazatelj kvalitete dobiti pokazuje kolika je razlika odnosno jaz između novčanih primitaka i priznatih prihoda i dobiti u određenome razdoblju. Okvirna referentna vrijednost ovih pokazatelja je 1,00 odnosno što je vrijednost pokazatelja bliže jedan, to znači da je veći dio priznate dobiti i prihoda ujedno i naplaćen, uz napomene i ograničenja koja su prethodno navedena. Rezultati deskriptivne analize novčanih pokazatelja kvalitete dobiti pokazuju da poduzeća čiji financijski izvještaji ne sadrže računovodstvene manipulacije u pravilu imaju bolje srednje (prosječne) vrijednosti pokazatelja kvalitete prodaje i dobiti u odnosu na poduzeća čiji financijski izvještaji sadrže utvrđene računovodstvene manipulacije.

Tablica 3. Analiza pokazatelja kvalitete dobiti prema računovodstvenim manipulacijama

\begin{tabular}{|l|l|r|r|}
\hline Stanje računovodstvenih manipulacija & \multicolumn{1}{c|}{ QRev } & \multicolumn{1}{c|}{ QPro } \\
\hline \multirow{4}{*}{$\begin{array}{l}\text { Pozitivno revizorsko } \\
\text { mišljenje }\end{array}$} & $\mathrm{N}$ & 138 & 155 \\
\cline { 2 - 4 } & Srednja vrijednost & 0,473993 & 0,858206 \\
\cline { 2 - 4 } & Medijan & 0,000000 & 0,555200 \\
\cline { 2 - 4 } & Standardna devijacija & 0,7050203 & 4,2503613 \\
\cline { 2 - 4 } & \% od ukupno & $60,3 \%$ & $63,0 \%$ \\
\hline \multirow{4}{*}{$\begin{array}{l}\text { Modificirano revizorsko } \\
\text { mišljenje }\end{array}$} & $\mathrm{N}$ & 9,422137 & 0,006948 \\
\cline { 2 - 4 } & Srednja vrijednost & 0,000000 & 0,059700 \\
\cline { 2 - 4 } & Medijan &, 6784124 & 4,3543830 \\
\cline { 2 - 4 } & Standardna devijacija & $39,7 \%$ & $37,0 \%$ \\
\cline { 2 - 4 } & $\%$ od ukupno & 229 & 246 \\
\hline \multirow{5}{*}{\begin{tabular}{l} 
Ukupno \\
\cline { 2 - 3 }
\end{tabular}} & N & 0,453386 & 0,543310 \\
\cline { 2 - 4 } & Srednja vrijednost & 0,000000 & 0,490000 \\
\cline { 2 - 4 } & Medijan & 0,6935344 & 4,3000264 \\
\cline { 2 - 4 } & Standardna devijacija & $100,0 \%$ & $100,0 \%$ \\
\cline { 2 - 4 } & \% od ukupno & & 91 \\
\hline
\end{tabular}

Izvor: rezultati istraživanja (N=246), SPSS v. 20. 
Naime, rezultatu prikazani u tablici 3. pokazuju da poduzeća bez računovodstvenih manipulacija u financijskim izvještajima prosječno naplate $47,39 \%$ svojih obračunanih i iskazanih prihoda od prodaje, dok kod poduzeća s računovodstvenim manipulacijama u financijskim izvještajima stupanj naplate fakturirane prodaje je manji i iznosi 42,21\%. Prosječna vrijednost pokazatelja kvalitete prodaje za sva poduzeća uključena u uzorak u promatranome razdoblju iznosi 45,33\% što je pokazatelj koji je ispod 50\% stupnja naplaćenosti iskazanih i priznatih prihoda te ukazuje na probleme u naplati potraživanja koji mogu utjecati na likvidnost poduzeća.

U pogledu pokazatelja kvalitete dobiti (vidjeti tablicu 3.) može se istaknuti da je iskazana dobit kvalitetnija kod poduzeća bez značajnih pogrešnih prikazivanja u financijskim izvještajima gdje je čak $85,82 \%$ iskazane dobiti ujedno i naplaćeno te raspoloživo poduzeću za daljnju raspodjelu, što je pokazatelj koji je na zadovoljavajućoj razini. S druge strane, kod poduzeća s računovodstvenim manipulacijama u financijskim izvještajima stupanj naplate iskazane dobiti je značajno manji i iznosi nezadovoljavajućih 0,69\% što ukazuje na postojanje značajnih razlika u kvaliteti dobiti mjerenih ovim novčanim pokazateljem između promatranih skupina poduzeća.

S ciljem utvrđivanja novčanih pokazatelja kvalitete dobiti koji mogu biti korisni u utvrđivanju računovodstvenih manipulacija u financijskim izvještajima poduzeća izvršeno je testiranje razlika u prosječnim vrijednostima pokazatelja primjenom neparametrijskih testova. U pogledu testiranja razlika u novčanim pokazateljima kvalitete dobiti između dvije skupine promatranih poduzeća, rezultati provedenoga Mann-Whitney U testa (vidjeti tablicu 4.) pokazuju da na razini značajnosti od 5\% postoji statistički značajna razlika kod novčanog pokazatelja kvalitete dobiti (QPro) ( $\mathrm{p}=0,029)$.

Primjenom Mann-Whitney U testa, kod novčanog pokazatelja kvalitete prodaje (QRev) ( $\mathrm{p}=0,548)$ nije utvrđena statistički značajna razlika između promatranih skupina. Temeljem dobivenih rezultata, može se zaključiti da novčani pokazatelji kvalitete dobiti mogu biti koristan indikator za utvrđivanje računovodstvenih manipulacija u financijskim izvještajima poduzeća, budući da postoji novčani pokazatelj kvalitete dobiti koji se značajno razlikuje između promatranih skupina poduzeća.

Tablica 4. Rezultati testiranja razlika kod novčanih pokazatelja kvalitete dobiti prema računovodstvenim manipulacijama (Mann-Whitney U test)

Hypothesis Test Summary

\begin{tabular}{|c|c|c|c|c|}
\hline & Null Hypothesis & Test & Sig. & Decision \\
\hline 1 & $\begin{array}{l}\text { The distribution of QRev is the } \\
\text { same across categories of mol. }\end{array}$ & $\begin{array}{l}\text { Independent- } \\
\text { Samples } \\
\text { Mann- } \\
\text { Whitney U } \\
\text { Test }\end{array}$ & .548 & $\begin{array}{l}\text { Retain the } \\
\text { null } \\
\text { hypothesis. }\end{array}$ \\
\hline 2 & $\begin{array}{l}\text { The distribution of QPro is the sam } \\
\text { across categories of hill. }\end{array}$ & $\begin{array}{l}\text { Independent- } \\
\text { Samples } \\
\text { Wann- } \\
\text { volhitney U } \\
\text { Test }\end{array}$ & .029 & $\begin{array}{l}\text { Reject the } \\
\text { null } \\
\text { hypothesis. }\end{array}$ \\
\hline
\end{tabular}

Asymptotic significances are displayed. The significance level is, 05 . 
Oblikovanje modela utjecaja novčanih pokazatelja kvalitete dobiti na utvrđivanje računovodstvenih manipulacija izvršeno je i primjenom logističke binarne regresije. Imajući $\mathrm{u}$ vidu da podatci u uzorku kod nezavisnih varijabli ne slijede normalnu distribuciju, za potrebe ovoga istraživanja primijenjena je binarna logistička regresija.

Tablica 5. Prikaz varijabli uključenih u model utjecaja novčanih pokazatelja kvalitete dobiti na utvrđivanje računovodstvenih manipulacija u financijskim izvještajima poduzeća

\begin{tabular}{|l|l|c|c|c|r|r|r|}
\hline \multicolumn{2}{|c|}{} & B & S.E. & Wald & $\begin{array}{c}\text { Stupnjevi } \\
\text { slobode df }\end{array}$ & $\begin{array}{c}\text { Značajnost } \\
\text { (Sig.) }\end{array}$ & Exp(B) \\
\hline \multirow{2}{*}{ Korak 2a $^{\text {a }}$} & QPro & $-0,088$ & 0,039 & 5,027 & 1 & 0,025 & 0,915 \\
\cline { 2 - 7 } & Konstanta & $-0,348$ & 0,141 & 6,145 & 1 & 0,013 & 0,706 \\
\hline a. Varijable uključene u koraku 1: QPro, QRev.
\end{tabular}

Izvor: rezultati istraživanja (N=219), SPSS v. 20.

Rezultati testiranja (vidjeti tablicu 5.) pokazuju da novčani pokazatelj kvalitete dobiti (QPro), na statistički značajnoj razini od 5\%, utječu na utvrđivanje računovodstvenih manipulacija u financijskim izvještajima poduzeća. Dobiveni model utjecaja novčanih pokazatelja kvalitete dobiti na utvrđivanje računovodstvenih manipulacija je statistički značajan i relevantan (Chi-square $=5,750 ; \mathrm{df}=1 ; \mathrm{p}=0,016$ ) odnosno predstavlja novčane pokazatelje kvalitete dobiti koji pozitivno utječu na utvrđivanje računovodstvenih manipulacija u financijskim izvještajima poduzeća na statistički signifikantnoj razini. Rezultati statističke analize predočeni u tablici 6. ukazuju na osnovna obilježja dobivenog modela. Vrijednost Nagelkerke R Square pokazatelja iznosi 0,035 što ukazuje koliko je varijacija u zavisnoj varijabli objašnjeno prediktorima. Ipak treba naglasiti da u statističkoj teoriji ne postoji suglasje kolika je optimalna vrijednost ovoga pokazatelja, a kod sveukupne ocjene modela treba ga razmatrati zajedno s drugim pokazateljima obilježja modela.

Tablica 6. Rezultati testova značajnosti modela utjecaja novčanih pokazatelja kvalitete dobiti na utvrđivanje računovodstvenih manipulacija u financijskim izvještajima poduzeća

\begin{tabular}{|c|c|c|c|c|c|c|}
\hline \multicolumn{7}{|c|}{ Omnibus test parametara modela } \\
\hline & & \multicolumn{2}{|c|}{ Hi-kvadrat } & \multicolumn{2}{|c|}{ Stupnjevi slobode } & Značajnost \\
\hline \multirow{3}{*}{ Korak $2^{\mathrm{a}}$} & Korak & & $-0,215$ & & 1 & 0,643 \\
\hline & Blok & & 5,750 & & 1 & 0,016 \\
\hline & Model & & 5,750 & & 1 & 0,016 \\
\hline \multicolumn{7}{|c|}{$\begin{array}{l}\text { a. Negativna Hi-kvadrat vrijednost ukazuje da se HI-kvadrat vrijednost smanjila u } \\
\text { odnosu na prethodni korak. }\end{array}$} \\
\hline \multicolumn{7}{|c|}{ Pregled modela } \\
\hline Korak & \multicolumn{2}{|c|}{-2 Log vjerojatnost } & \multicolumn{2}{|c|}{ Cox \& Snell R Square } & \multicolumn{2}{|c|}{ Nagelkerke R Square } \\
\hline 1 & \multicolumn{2}{|c|}{$289,135 \mathrm{a}$} & \multicolumn{2}{|c|}{0,027} & \multicolumn{2}{|r|}{0,036} \\
\hline 2 & \multicolumn{2}{|c|}{$289,351 \mathrm{a}$} & \multicolumn{2}{|r|}{0,026} & \multicolumn{2}{|r|}{0,035} \\
\hline
\end{tabular}




\begin{tabular}{|c|c|c|c|}
\hline \multicolumn{4}{|c|}{ Hosmer i Lemeshow test } \\
\hline Korak & Hi-kvadrat & Stupnjevi slobode & Značajnost \\
\hline 1 & 12,041 & 8 & 0,149 \\
\hline 2 & 10,411 & 8 & 0,237 \\
\hline
\end{tabular}

Izvor: rezultati istraživanja (N=219), SPSS v. 20.

Hosmer i i Lemeshow test ukazuje koliko je model dobro prilagođen podatcima, a statistička značajnost testa bi trebala biti veća od $0,05(\mathrm{p}>0,05)$. U konkretnome slučaju statistička značajnost Hosmer i i Lemeshow testa je veća od $0,05(\mathrm{p}=0,237)$ što ukazuje da je model dobro prilagođen podatcima.

Vrijednosti beta koeficijenata uz prediktore pokazuju smjer i intenzitet utjecaja pojedinog pokazatelja na utvrđivanje značajnog pogrešnog prikazivanja u financijskim izvještajima. Iz vrijednosti koeficijenta uz pokazatelje može se utvrditi stupanj i smjer utjecaja odabranih pokazatelja na utvrđivanje računovodstvenih manipulacija u financijskim izvještajima poduzeća. Kod pokazatelja kvalitete dobiti (QPro) vrijednost beta koeficijenta iznosi $B=-0,088$ što znači da novčani pokazatelj kvalitete dobiti, na statistički značajnoj razini $(\mathrm{p}=0,025)$, utječe na utvrđivanje računovodstvenih manipulacija u financijskim izvještajima poduzeća. Nadalje, negativan predznak uz beta koeficijent $(B=-0,088)$ kod pokazatelja kvalitete dobiti (QPro) ukazuje na činjenicu da veća vrijednost pokazatelja kvalitete dobiti (QPro) doprinosi manjoj vrijednosti modela odnosno manjoj vjerojatnosti računovodstvenih manipulacija u financijskim izvještajima. Rezultati su logični i očekivani, ako se uzmu u obzir i rezultati prethodno provedene analize koja je pokazala da kod pokazatelja kvalitete dobiti postoji značajna razlika između dvije promatrane skupine poduzeća na statistički značajnoj razini, kao i da poduzeća bez računovodstvenih manipulacija u financijskim izvještajima poduzeća imaju bolju prosječnu kvalitetu dobiti mjerenu stupnjem naplaćenosti iste.

Zanimljivo je analizirati i vrijednost količnika vjerojatnosti (Exp(B) kod odabranih pokazatelja uključenih u model utjecaja novčanih pokazatelja kvalitete dobiti na utvrđivanje računovodstvenih manipulacija u financijskim izvještajima. Količnik vjerojatnosti kod koeficijenta obrtaja ukupne imovine (QPro) iznosi 0,915 što podrazumijeva da ukoliko se pokazatelj kvalitete dobiti poveća za 1,00, smanjuje se vjerojatnost da se računovodstvene manipulacije pojave u financijskim izvještajima za $8,50 \%$. Drugim riječima, ukoliko se stupanj prosječne novčane naplaćenosti dobiti mjerene novčanim pokazateljem kvalitete dobiti (QPro) poveća za $1,00 \%$, smanjuje se vjerojatnost pojave računovodstvenih manipulacija u financijskim izvještajima za 8,50\%. To dodatno ukazuje na povezanost ovoga prediktora sa zavisnom varijablom i njegovu sposobnost utvrđivanja računovodstvenih manipulacija u financijskim izvještajima.

\section{ZAKLJUČAK}

Temeljem prethodno iznesenoga, može se zaključiti da su financijski izvještaji koristan i važan izvor informacija za donošenje različitih poslovnih odluka. Rezultati provedenoga istraživanja ukazuju da pokazatelji kvalitete dobiti koji se temelje na novčanoj osnovi kao rezultat analize financijskih izvještaja pozitivno utječu na utvrđivanje računovodstvenih manipulacija u financijskim izvještajima poduzeća. Naime, kod novčanog pokazatelja 
kvalitete dobiti (QPro) postoji značajna razlika na razini značajnosti od 5\% između poduzeća $s$ računovodstvenim manipulacijama u financijskim izvještajima i poduzeća bez računovodstvenih manipulacija u financijskim izvještajima. Nadalje, oblikovan je model utjecaja koji je pokazao da novčani pokazatelj kvalitete dobiti (QPro) doprinosi utvrđivanju računovodstvenih manipulacija u financijskim izvještajima poduzeća. Konačno, može se zaključiti da novčani pokazatelji kvalitete dobiti predstavljaju koristan instrument u utvrđivanju računovodstvenih manipulacija u financijskim izvještajima poduzeća. U narednim istraživanjima, može se razmotriti utjecaj novčanih pokazatelja kvalitete dobiti na utvrđivanje računovodstvenih manipulacija u financijskim izvještajima po pojedinim djelatnostima. Također, zanimljivo bi bilo provesti komparativnu analizu utjecaja pokazatelja kvalitete dobiti koji se temelje na obračunskoj osnovi u odnosu na one koji se temelje na novčanoj osnovi, na utvrđivanje računovodstvenih manipulacija u financijskim izvještajima poduzeća.

\section{LITERATURA:}

1. Aljinović Barać, Ž., Klepo, T. (2006). Features of accounts manipulations in Croatia. Zbornik radova Ekonomskog fakulteta u Rijeci - Časopis za ekonomsku teoriju i praksu 24 (2), str. 273-290.

2. Bayley, L., Taylor, S. (2007). Identifying earnings overstatements: A practical test. Working paper, ABN Amro Sydney and University of New South Wales

3. Beneish, M. D. (1997). Detecting GAAP Violation: Implications for Assessing Earnings Management among Firms with Extreme Financial Performance. Journal of Accounting and Public Policy 16, str. 271-309.

4. Beneish, M. D. (1999). The Detection of Earnings Manipulation, Financial Analyst Journal, str. 24-36.

5. Cuzdriorean, D. D. (2013). Most recent findings in earnings management area: interesting insights from traditionally top 5 leading accounting journals. Annales Universitatis Apulensis Series Oeconomica, 15(2), str. 402-416.

6. Dechow, P. M., I. Dichev (2002). The quality of accruals and earnings: The role of accrual estimation errors. The Accounting Review 77 (Supplement), str. 35-59.

7. Dechow, P., Skinner, D. (2000). Earnings management: Reconciling the views of accounting academics, practitioners, and regulators. Accounting Horizons, Vol. 14, No 2, str. 235-250.

8. Dechow, P. M., Ge, Weili Larson, Chad R. Sloan, Richard G. (2010). Predicting Material Accounting Misstatements. Contemporary Accounting Research, Forthcoming; AAA 2008 Financial Accounting and Reporting Section (FARS) Paper. (SSRN: http://ssrn.com/abstract=997483, dostupno 15. 1. 2017. godine, pristup 15. 1. 2017.)

9. Figlewicz, R. E, Zeller, T. L. (1991). An Analysis of Performance, Liqudity, Coverage and Capital Ratios from the Statement of Cash Flows. Akron Business and Economic Review, Spring 1991, Vol 22, No 1, str. 64-81.

10. Gulin, D. (2002.). Manipulacije na financijskim tržištima i njihov utjecaj na financijske izvještaje. Računovodstvo, financije i revizija u suvremenim gospodarskim uvjetima, XXXVII. simpozij Pula, Zagreb: HZRiF. 
11. Healy, P. M., Wahlen, J. M. (1999). A Review of the Earnings Management Literature and its Implications for Standard Setting. Accounting Horizons, 13 (4), str. 365-383.

12. Jameson, M. (1988). A practical Guide to Creative Accounting. London: Kogan Page.

13. Jones, J. J. (1991). Earnings management during import relief investigations. Journal of Acounting Research 29, str. 193-228.

14. Korcan, B., Dechow, P., Yuan, S., Wang, A. (2013). The Use of Financial Ratio Models to Help Investors Predict and Interpret Significant Corporate Events. Working paper: http://ssrn.com/abstract=2335185, dostupno 25.01.2017. godine, str. 1-75.

15. Prevoo, L. J. N. (2007). Detecting earnings management - a critical assessment of the Beneish model. Universiteit Maastricht Faculty of economics and business administration, Maastricht, str. 1-60.

16. Ronen, J., Yaari, V. (2008). Earnings Management. Emerging Insights in Theory, Practice, and Research, Springer.

17. Savez računovođa, revizora i financijskih djelatnika FBiH (2017.). Međunarodni računovodstveni standardi / Međunarodni standardi financijskog izvještavanja (MSFI/MRS). Mostar.

18. Schipper, K. (1989). Commentary on earnings management. Accounting Horizons, Vol. 3, No 4, str. 91-102.

19. Sever Mališ, S., Tušek, B., Žager, L. (redaktor: Žager, L.) (2012.). Revizija: načela, standardi, postupci. HZRFD, Zagreb, ISBN 978-953-277-072-8.

20. Stolowy, H., Breton G. (2000). A Review of research on accounts manipulation. Presentation at the 23rd Annual Congress of the European Accounting Association, Munich, Germany, March, str. 29-31.

21. Tušek, B.; Žager, L. (2007.). Revizija, drugo izmijenjeno i dopunjeno izdanje. Zagreb: HZRiF.

22. Zakon o Komisiji za vrijednosne papire u Federaciji Bosne i Hercegovine (,,Službene novine Federacije Bosne i Hercegovine“, broj 39/98., 36/99., 33/04. i 92/13.).

23. Zakon o Registru vrijednosnih papira (,Službene novine Federacije Bosne i Hercegovine“, broj 39/98., 36/99. i 33/04.).

24. Zakon o tržištu vrijednosnih papira (,Službene novine Federacije Bosne i Hercegovine“" broj 85/08. i 109/12.).

25. Žager, L., Žager, K., Mamić Sačer, I., Sever, S. (2008.). Analiza financijskih izvještaja. Masmedia, Zagreb. 